\title{
53. PETROLOGY AND GEOCHEMISTRY OF BASEMENT ROCKS RECOVERED ON LEG 37, DSDP
}

\author{
W.B. Bryan, G. Thompson, Woods Hole Oceanographic Institution, Woods Hole, Massachusetts \\ and \\ F.A. Frey, J.S. Dickey, Jr., and S. Roy, Massachusetts Institute of Technology, Cambridge, Massachusetts
}

\section{INTRODUCTION}

Petrography, mineral analyses, and bulk major and trace element analyses are presented for selected samples from Sites 332, 333, 334, and 335 of DSDP Leg 37.

Petrographic observations were made on small polished thin sections or on glass chips which also served as mounts for microprobe analyses. Our major petrographic emphasis was on microphenocrysts and skeletal quench phases in glasses and microphenocrysts in crystalline samples as these are considered to be most diagnostic of magma composition.

Natural glass and mineral compositions were determined directly by electron microprobe analysis. Bulk major element analyses of crystalline samples were determined by microprobe analysis of fluxed glasses. Trace elements were determined by emission spectrometry and neutron activation. These methods, their precision and accuracy, were discussed by Frey et al. (1974). Four of the analyzed samples from Leg 37 are powders selected for interlaboratory comparison purposes; analyses of those samples are given in Wright (this volume). Sample 335-8-3, 98-101 cm, a natural glass, was analyzed directly by microprobe and also as a fluxed glass; agreement of the analyses is good. The precision of the trace element analyses can be estimated by comparing data for fresh and altered portions of the same samples, or repetitive analyses of certain core splits, e.g., 333A-3-1, 74-77 $\mathrm{cm}$ and 333A-3-1, 75-76 cm.

Where fresh and altered portions of samples have been analyzed, alteration has caused an increase in $\mathrm{H}_{2} \mathrm{O}, \mathrm{Fe}_{2} \mathrm{O}_{3} / \mathrm{FeO}, \mathrm{K}_{2} \mathrm{O}$, B, and $\mathrm{Li}$. Other element abundances are unaffected and thus these elements are useful for petrologic interpretations. Weathered portions containing carbonate-rich areas have been avoided; our data indicate that samples with appreciable carbonate $\left(>5 \% \mathrm{CO}_{2}\right)$ show an increase in $\mathrm{Ca}$ and $\mathrm{Sr}$, but other elements are only "diluted" by the calcite matrix.

The chemical analyses are presented separately in the appropriate site reports (Chapters 2-5, this volume); mineral analyses are given in Tables $1,2,3$ and 4 . In addition to the DSDP sample numbering system we have identified each sample according to the shipboarddefined lithologic and chemical unit. In this report we briefly summarize and interpret our observations and data.

\section{PETROGRAPHY AND CHEMISTRY}

\section{Hole 332A}

Lithologic Unit 2; chemical unit b; Samples 8-1, 47. $48 \mathrm{~cm} ; 8-1,56-64 \mathrm{~cm} ; 8-1,120-122 \mathrm{~cm} ; 8-2,2-15 \mathrm{~cm}$.
Lithologic Unit 5; chemical unit b; Sample 26-1, 104$108 \mathrm{~cm}$. Lithologic Unit 7; chemical unit b; Sample 402, $133-135 \mathrm{~cm}$.

These samples, from three different lithologic units, are very similar in chemical composition. The glasses from 8-1 contain microphenocrysts of olivine, plagioclase, and augite, and thus they appear to lie on a threephase olivine-plagioclase-pyroxene-cotectic. The microphenocryst growth forms are typical of quenched lavas in which either olivine or pyroxene may occur alone; there is no evidence of a reaction relationship between these minerals. Augite crystals commonly form a "knot" at the centers of radiating plagioclasepyroxene-glomerocrysts. Coexisting olivine and pyroxene are not present in the crystalline interiors; for example, Sample 8-1, 120-122 cm has pyroxene-plagioclase "bow-tie" intergrowths, and Sample 40-2, 133-135 cm has plagioclase with rare olivine microphenocrysts.

Olivines from Core 8, Section 1 are similar in composition averaging about $\mathrm{Fo}_{83}$. Coexisting pyroxenes are intermediate in iron enrichment $\left(\mathrm{Ca}_{36} \mathrm{Mg}_{53} \mathrm{Fe}_{10}\right)$ compared to pyroxenes in Hole 332B and Site 334 . Plagioclase in Core 26, Section 1 has relatively high $\mathrm{FeO}, \mathrm{MgO}$, and excess $\mathrm{Ca}$ and $\mathrm{Si}$ relative to $\mathrm{Al}$. These chemical features can be explained by a substitution of the form $\mathrm{Ca}\left(\mathrm{Fe}^{2+} \mathrm{Mg}\right) \mathrm{Si}_{3} \mathrm{O}_{8}$ (Bryan, 1974).

Chemically these samples are similar in composition, and they appear to be among the most "evolved" or fractionated of the Leg 37 samples we analyzed. This is indicated by the high $\mathrm{FeO}^{*} / \mathrm{MgO}(>1.3), \mathrm{TiO}_{2}(>1.0)$, $\mathrm{Ba}(>20 \mathrm{ppm}), \mathrm{V}(>250 \mathrm{ppm})$, and $\mathrm{Zr}(>80 \mathrm{ppm})$ contents, and low $\mathrm{Cr}(<75 \mathrm{ppm})$ and $\mathrm{Ni}(<60 \mathrm{ppm})$ concentrations. The rare earth elements (REE) are 10-16X chondritic values and the light rare earth elements (LREE) are slightly enriched relative to chondritic distribution. Furthermore, these basalts plot on the most fractionated end of the $\mathrm{TiO}_{2}-\mathrm{FeO}^{*} / \mathrm{MgO}$, and $\mathrm{V}-\mathrm{Zr}$ trends for Leg 37 samples (Figures 1 and 2). These basalts are similar in some respects to fractionated lavas from DSDP Leg 3 (Frey et al., 1974).

Lithologic Unit 7; chemical unit h?; Sample 40-2, 26$33 \mathrm{~cm}$.

This sample (received only as a powder) differs from other Hole 332A units we examined. Because of the high abundances of $\mathrm{Al}, \mathrm{Ca}, \mathrm{Cr}$, and $\mathrm{Ni}$ and a small positive Eu anomaly, this sample must be a cumulate rock. Other elements appear to be "diluted" by the cumulate phases-probably plagioclase and olivine. Despite the relatively low $\mathrm{FeO}^{*} / \mathrm{MgO}$ and $\mathrm{TiO}_{2}$ content, the concentrations of large ion lithophile (LIL) elements such as $\mathrm{Ba}, \mathrm{V}$, and $\mathrm{Zr}$ are not unusually low 
TABLE 1

Leg 37 Hole 332A Mineral Analyses

\begin{tabular}{|c|c|c|c|c|c|c|c|c|}
\hline & \multirow{2}{*}{$\frac{\text { Plagioclase }}{1}$} & \multicolumn{5}{|c|}{ Olivine } & \multicolumn{2}{|c|}{ Pyroxene } \\
\hline & & 2 & 3 & 4 & 5 & 6 & 7 & 8 \\
\hline $\mathrm{SiO}_{2}$ & 47.46 & 39.03 & 39.68 & 39.51 & 39.25 & 39.24 & 52.65 & 51.40 \\
\hline $\mathrm{TiO}_{2}$ & 0.00 & 0.00 & 0.04 & 0.00 & 0.00 & 0.04 & 0.56 & 0.55 \\
\hline $\mathrm{Al}_{2} \mathrm{O} 3$ & 32.86 & 0.07 & 0.05 & 0.05 & 0.10 & 0.07 & 3.56 & 3.31 \\
\hline $\mathrm{FeO}$ & 0.56 & 16.14 & 15.67 & 16.25 & 16.34 & 15.94 & 6.69 & 6.54 \\
\hline $\mathrm{MnO}$ & 0.01 & 0.25 & 0.27 & 0.27 & 0.25 & 0.27 & 0.15 & 0.16 \\
\hline $\mathrm{MgO}$ & 0.25 & 44.63 & 44.39 & 44.78 & 45.00 & 44.99 & 18.95 & 19.08 \\
\hline $\mathrm{CaO}$ & 17.38 & 0.35 & 0.34 & 0.32 & 0.35 & 0.33 & 18.03 & 18.15 \\
\hline $\mathrm{Na}_{2} \mathrm{O}$ & 1.81 & 0.07 & 0.02 & 0.02 & 0.04 & 0.02 & 0.24 & 0.25 \\
\hline $\mathrm{K}_{2} \mathrm{O}$ & 0.03 & 0.00 & 0.00 & 0.00 & 0.00 & 0.00 & 0.00 & 0.00 \\
\hline $\mathrm{Cr}_{2} \mathrm{O}_{3}$ & 0.01 & 0.00 & 0.10 & 0.02 & 0.03 & 0.11 & 0.12 & 0.11 \\
\hline \multirow[t]{3}{*}{ Total } & 100.37 & 100.55 & 100.56 & 101.21 & 101.39 & 101.02 & 100.96 & 99.56 \\
\hline & \multicolumn{8}{|c|}{ Cations } \\
\hline & 8 Oxygen & \multicolumn{5}{|c|}{4 Oxygen } & \multicolumn{2}{|c|}{6 Oxygen } \\
\hline $\mathrm{Si}$ & 2.183 & 0.982 & 0.995 & 0.987 & 0.980 & 0.981 & 1.901 & 1.888 \\
\hline $\mathrm{Ti}$ & 0.000 & 0.000 & 0.000 & 0.000 & 0.000 & 0.000 & 0.015 & 0.015 \\
\hline $\mathrm{A} 1$ & 1.770 & 0.001 & 0.000 & 0.000 & 0.002 & 0.001 & 0.151 & 0.143 \\
\hline $\mathrm{Fe}$ & 0.022 & 0.340 & 0.328 & 0.339 & 0.341 & 0.333 & 0.201 & 0.200 \\
\hline $\mathrm{Mn}$ & 0.000 & 0.005 & 0.005 & 0.005 & 0.005 & 0.005 & 0.004 & 0.004 \\
\hline $\mathrm{Mg}$ & 0.017 & 1.675 & 1.659 & 1.667 & 1.676 & 1.678 & 1.019 & 1.044 \\
\hline $\mathrm{Ca}$ & 0.858 & 0.009 & 0.009 & 0.008 & 0.009 & 0.009 & 0.697 & 0.713 \\
\hline $\mathrm{Na}$ & 0.160 & 0.003 & 0.000 & 0.000 & 0.001 & 0.000 & 0.016 & 0.017 \\
\hline $\mathrm{K}$ & 0.000 & 0.000 & 0.000 & 0.000 & 0.000 & 0.000 & 0.000 & 0.000 \\
\hline $\mathrm{Cr}$ & 0.000 & 0.000 & 0.000 & 0.000 & 0.000 & 0.001 & 0.003 & 0.002 \\
\hline Total & 5.010 & 3.015 & 2.998 & 3.007 & 3.014 & 3.010 & 4.006 & 4.027 \\
\hline
\end{tabular}

Note: $1=26-1,104-108 \mathrm{~cm}$ plagioclase phenocryst; $2=8-1,47 \mathrm{~cm}$ olivine in glass; $3=8-1$ $47 \mathrm{~cm}$ olivine microphenocryst in glass; $4=8-1,56-64 \mathrm{~cm}$ olivine in glass; $5=8-1,56-64$ $\mathrm{cm}$ olivine in glass; $6=8-1,56-64 \mathrm{~cm}$ olivine in glass; $7=8-1,47 \mathrm{~cm}$ pyroxene in glass; $8=8-1,56-64$ pyroxene in glass.

for Mid-Atlantic Ridge basalts. The REE are 5-7X chondrites but slight LREE enrichment is present as in other Hole 332A rocks (Figure 3). Thus we suggest that this cumulate rock is genetically related to the more evolved Hole $332 \mathrm{~A}$ basalts.

\section{Hole 332B}

Lithologic Unit $l_{(2)}$ chemical unit a; Samples 3-2, 98$101 \mathrm{~cm} ; 3-3,14-17 \mathrm{~cm} ; 3-3,77-80 \mathrm{~cm} ; 3-4,26-36 \mathrm{~cm} ; 3-4$, $40-43 \mathrm{~cm} ; 3-4,98-101 \mathrm{~cm}$.

These are basalts containing $30 \%-50 \%$ subhedral plagioclase xenocrysts or phenocrysts. Olivine microphenocrysts are present in all samples. The groundmass is a subophitic intergrowth of plagioclase and pyroxene sometimes including distinct magnetite octahedra.

Because of its LIL-element depleted character, this unit differs markedly from Hole 332A Unit 3. High $\mathrm{Al}_{2} \mathrm{O}_{3}$ and $\mathrm{CaO}$ clearly reflect the cumulate plagioclase and this "dilution" effect may account for the relatively low abundances of some trace elements as well as the low alkalies, titanium, and iron. However, the LREE are slightly depleted relative to chondrites, and other ratios, such as $\mathrm{FeO}^{*} / \mathrm{MgO}$, are low. This suggests a less fractionated magma and is in agreement with petrographic evidence that olivine, not pyroxene, is the liquidus phase. Indeed this unit, with the exception of the Site 334 plutonic rocks, plots at the least fractionated end of the $\mathrm{TiO}_{2}-\mathrm{FeO} * / \mathrm{MgO}$ and $\mathrm{V}-\mathrm{Zr}$ trends (Figures 1 and 2).

Lithologic Unit 2(4); chemical unit c; Sample 6-2, 122 $125 \mathrm{~cm}$.

This unit is represented by a microdolerite with scattered plagioclase and phenocrysts and distinct magnetite octahedra. There is some preferential alteration of pyroxene. Chemically this unit is more fractionated than Unit 1 of this site; for example, it has distinctly higher $\mathrm{FeO}^{*} / \mathrm{MgO}$ and abundances of $\mathrm{Ti}, \mathrm{Ba}, \mathrm{V}$, $\mathrm{Zr}$, and REE. The REE abundances are nearly unfractionated with respect to chondrite (Figure 3).

Lithologic Unit $3 \mathrm{~A}_{(6)}$ and 17 ; chemical unit d; Samples $8-1,50-53 \mathrm{~cm} ; 11-3,75-78 \mathrm{~cm}$.

Glass from 8-1 contains euhedral olivine microphenocrysts and rare plagioclase microphenocrysts. The olivines are more iron rich than most olivines from Hole 332B; this together with the chemical data suggest that this is a fractionated lava. The sample from 11-3 contains irregular and corroded subhedral to anhedral plagioclase xenocrysts with distinct oscillatory zoning 
TABLE 2

Leg 37 Hole 332B Mineral Analyses

\begin{tabular}{|c|c|c|c|c|c|c|c|c|c|c|c|c|c|c|c|}
\hline & \multicolumn{6}{|c|}{ Plagioclase } & \multicolumn{8}{|c|}{ Olivine } & \multirow{2}{*}{$\begin{array}{c}\text { Pyroxene } \\
15\end{array}$} \\
\hline & 1 & 2 & 3 & 4 & 5 & 6 & 7 & 8 & 9 & 10 & 11 & 12 & 13 & 14 & \\
\hline $\mathrm{SiO}_{2}$ & 48.86 & 49.50 & 49.94 & 51.20 & 51.59 & 50.40 & 39.71 & 39.47 & 39.49 & 39.53 & 39.30 & 39.80 & 40.11 & 40.04 & 51.39 \\
\hline $\mathrm{TiO}_{2}$ & 0.00 & 0.00 & 0.00 & 0.06 & 0.01 & 0.00 & 0.04 & 0.02 & 0.02 & 0.01 & 0.00 & 0.00 & 0.01 & 0.00 & 0.62 \\
\hline $\mathrm{A}_{2}{ }_{2} \mathrm{O}_{3}$ & 33.58 & 31.51 & 31.71 & 29.23 & 30.18 & 30.74 & 0.08 & 0.16 & 0.07 & 0.06 & 0.09 & 0.11 & 0.12 & 0.08 & 2.45 \\
\hline $\mathrm{FeO}$ & 0.42 & 0.39 & 0.39 & 1.13 & 0.75 & 0.66 & 15.08 & 14.83 & 13.75 & 13.68 & 0.15 & 9.77 & 11.52 & 9.51 & 10.65 \\
\hline $\mathrm{MnO}$ & 0.03 & 0.03 & 0.03 & 0.03 & 0.03 & 0.04 & 0.24 & 0.20 & 0.20 & 0.18 & 0.18 & 0.14 & 0.16 & 0.15 & 0.23 \\
\hline $\mathrm{MgO}$ & 0.04 & 2.70 & 0.28 & 0.61 & 0.43 & 0.27 & 45.25 & 45.05 & 45.99 & 46.48 & 49.11 & 49.35 & 48.94 & 50.19 & 16.30 \\
\hline $\mathrm{CaO}$ & 15.00 & 15.98 & 15.83 & 14.30 & 14.50 & 14.89 & 0.34 & 0.38 & 0.30 & 0.31 & 0.30 & 0.21 & 0.30 & 0.33 & 17.66 \\
\hline $\mathrm{Na}_{2} \mathrm{O}$ & 2.71 & 2.79 & 2.64 & 3.39 & 3.38 & 3.11 & 0.02 & 0.05 & 0.07 & 0.04 & 0.06 & 0.07 & 0.05 & 0.05 & 0.23 \\
\hline $\mathrm{K}_{2} \mathrm{O}$ & 0.04 & 0.02 & 0.02 & 0.04 & 0.02 & 0.04 & 0.00 & 0.00 & 0.00 & 0.00 & 0.00 & 0.00 & 0.00 & 0.00 & 0.00 \\
\hline $\mathrm{Cr}_{2} \mathrm{O}_{3}$ & 0.00 & 0.00 & 0.00 & 0.00 & 0.01 & 0.00 & 0.10 & 0.06 & 0.03 & 0.04 & 0.06 & 0.06 & 0.07 & 0.08 & 0.18 \\
\hline \multirow[t]{3}{*}{ Total } & 100.86 & 100.40 & 100.84 & 99.99 & 100.91 & 100.14 & 100.86 & 100.23 & 99.91 & 100.34 & 99.30 & 99.63 & 101.29 & 100.43 & 99.72 \\
\hline & & & & & & & Cations & & & & & & & & \\
\hline & \multicolumn{6}{|c|}{8 Oxygen } & \multicolumn{8}{|c|}{4 Oxygen } & 6 Oxygen \\
\hline $\mathrm{Si}$ & 2.214 & 2.261 & 2.268 & 2.344 & 2.336 & 2.304 & 0.990 & 0.989 & 0.989 & 0.984 & 0.975 & 0.982 & 0.980 & 0.978 & 1.917 \\
\hline $\mathrm{Ti}$ & 0.000 & 0.000 & 0.000 & 0.005 & 0.000 & 0.000 & 0.000 & 0.000 & 0.000 & 0.000 & 0.000 & 0.000 & 0.000 & 0.000 & 0.016 \\
\hline A1 & 1.792 & 1.696 & 1.697 & 1.579 & 1.612 & 1.653 & 0.002 & 0.004 & 0.001 & 0.001 & 0.002 & 0.002 & 0.002 & 0.002 & 0.107 \\
\hline $\mathrm{Fe}$ & 0.016 & 0.014 & 0.014 & 0.044 & 0.027 & 0.025 & 0.313 & 0.310 & 0.288 & 0.284 & 0.212 & 0.201 & 0.235 & 0.194 & 0.332 \\
\hline Mn & 0.000 & 0.000 & 0.000 & 0.000 & 0.000 & 0.003 & 0.004 & 0.003 & 0.003 & 0.003 & 0.002 & 0.002 & 0.002 & 0.002 & 0.006 \\
\hline $\mathrm{Mg}$ & 0.016 & 0.019 & 0.019 & 0.041 & 0.030 & 0.019 & 1.682 & 1.683 & 1.717 & 1.725 & 1.816 & 1.814 & 1.783 & 1.828 & 0.905 \\
\hline $\mathrm{Ca}$ & 0.727 & 0.782 & 0.770 & 0.701 & 0.705 & 0.728 & 0.008 & 0.009 & 0.007 & 0.008 & 0.007 & 0.005 & 0.007 & 0.008 & 0.706 \\
\hline $\mathrm{Na}$ & 0.236 & 0.236 & 0.230 & 0.302 & 0.294 & 0.274 & 0.000 & 0.002 & 0.003 & 0.001 & 0.002 & 0.003 & 0.001 & 0.002 & 0.016 \\
\hline K & 0.001 & 0.001 & 0.000 & 0.000 & 0.000 & 0.000 & 0.000 & 0.000 & 0.000 & 0.000 & 0.000 & 0.000 & 0.000 & 0.000 & 0.000 \\
\hline $\mathrm{Cr}$ & 0.000 & 0.000 & 0.000 & 0.000 & 0.000 & 0.000 & 0.001 & 0.000 & 0.000 & 0.000 & 0.000 & 0.000 & 0.000 & 0.001 & 0.004 \\
\hline Total & 5.002 & 5.008 & 4.998 & 5.016 & 5.004 & 5.006 & 3.001 & 3.002 & 3.010 & 3.007 & 3.017 & 3.013 & 3.013 & .3 .016 & 4.009 \\
\hline
\end{tabular}

Note: $1=22-3,47-53 \mathrm{~cm}$ plagioclase microphenocryst $2=22-3,47-53 \mathrm{~cm}$ plagioclase phenocryst; $3=22-3,47-53 \mathrm{~cm}$ plagioclase phenocryst $; 4=22-3,47-53 \mathrm{~cm}$ plagioclase microphenocrysts; $5=22-3,47-53 \mathrm{~cm}$ plagioclase "belt-buckle"; $6=43-3,109-110 \mathrm{~cm}$ plagioclase in glass; $7=8-1,50-53 \mathrm{~cm}$ olivine microphenocryst in glass; $8=22-3,47-53$ $\mathrm{cm}$ olivine microphenocryst; $9=22-3,47-53 \mathrm{~cm}$ olivine phenocryst $; 0=22-3,47-53 \mathrm{~cm}$ olivine phenocryst $; 11=35-2,62-65 \mathrm{~cm}$ fractured olivine $; 12=35-2,62-65 \mathrm{~cm}$ olivine phenocryst; $13=35-2,62-65 \mathrm{~cm}$ olivine microphenocryst; $14=35-2,62-65 \mathrm{~cm}$ olivine with pressure shadows; $15=25-4,19-21 \mathrm{~cm}$ pyroxene microphenocryst. 
TABLE 3

Leg 37 Site 334 Mineral Analyses

\begin{tabular}{|c|c|c|c|c|c|}
\hline & \multicolumn{4}{|c|}{ Pyroxene } & \multirow{2}{*}{$\begin{array}{c}\text { Plagioclase } \\
5\end{array}$} \\
\hline & 1 & 2 & 3 & 4 & \\
\hline $\mathrm{SiO}_{2}$ & 52.25 & 55.05 & 53.80 & 52.96 & 47.44 \\
\hline $\mathrm{TiO}_{2}$ & 0.28 & 0.11 & 0.20 & 0.21 & $\operatorname{Tr}$ \\
\hline $\mathrm{Al}_{2} \mathrm{O}_{3}$ & 4.04 & 1.29 & 2.10 & 2.35 & 33.55 \\
\hline $\mathrm{FeO}$ & 4.75 & 13.13 & 10.47 & 6.38 & 0.49 \\
\hline $\mathrm{MnO}$ & 0.15 & 0.35 & 0.30 & 0.23 & 0.00 \\
\hline $\mathrm{MgO}$ & 18.16 & 28.15 & 21.15 & 15.94 & 0.07 \\
\hline $\mathrm{CaO}$ & 20.13 & 2.08 & 12.36 & 22.01 & 17.20 \\
\hline $\mathrm{Na}_{2} \mathrm{O}$ & 0.18 & 0.00 & 0.18 & 0.21 & 1.76 \\
\hline $\mathrm{K}_{2} \mathrm{O}$ & 0.00 & 0.00 & 0.00 & 0.00 & 0.00 \\
\hline $\mathrm{Cr}_{2} \mathrm{O}_{3}$ & 1.14 & 0.16 & 0.29 & 0.30 & 0.04 \\
\hline Total & 101.07 & 100.31 & 100.84 & 100.60 & 100.56 \\
\hline \multicolumn{6}{|c|}{ Cations } \\
\hline \multicolumn{5}{|c|}{6 Oxygen } & 8 Oxygen \\
\hline $\mathrm{Si}$ & 1.884 & 1.964 & 1.944 & 1.938 & 2.168 \\
\hline $\mathrm{Ti}$ & 0.007 & 0.002 & 0.005 & 0.005 & - \\
\hline $\mathrm{Al}$ & 0.171 & 0.053 & 0.089 & 0.101 & 1.808 \\
\hline $\mathrm{Fe}$ & 0.143 & 0.392 & 0.316 & 0.194 & 0.017 \\
\hline $\mathrm{Mn}$ & 0.004 & 0.010 & 0.008 & 0.006 & - \\
\hline $\mathrm{Mg}$ & 0.976 & 1.497 & 1.136 & 0.869 & 0.004 \\
\hline $\mathrm{Ca}$ & 0.778 & 0.078 & 0.478 & 0.862 & 0.843 \\
\hline $\mathrm{Na}$ & 0.011 & - & 0.011 & 0.014 & 0.156 \\
\hline K & 0.000 & - & - & - & - \\
\hline $\mathrm{Cr}$ & 0.032 & 0.004 & 0.007 & 0.008 & 0.001 \\
\hline Total & 4.005 & 4.000 & 3.998 & 3.998 & 4.996 \\
\hline
\end{tabular}

Note: $1=16-3,24-31 \mathrm{~cm}$ pyroxene microphenocryst; $2=21-1$, $36-47 \mathrm{~cm}$ hypersthene in gabbro; $3=21-1,36-47 \mathrm{~cm}$ lamella in exsolved augite, gabbro; $4=21-1,36-47 \mathrm{~cm}$ lamella in exsolved augite, gabbro; $5=21-1,36-47 \mathrm{~cm}$ plagioclase, gabbro.

and traces of sector zoning in the core. The matrix is doleritic and consists of complex radial intergrowths of plagioclase and pyroxene.

Chemically this unit resembles Unit 2 of Hole 332B. $\mathrm{Cr}$ and $\mathrm{Ni}$ are slightly higher, and $\mathrm{Ti}$ and $\mathrm{V}$ are slightly lower in concentration in Unit 3 compared to 2. These units are similar to the fractionated lavas of Unit 3 at Hole 332A. For example, note the similar slight degrees of light REE enrichment in Unit 3 of Hole $332 \mathrm{~A}$ and 332B (Figure 3).

Lithologic Unit 4(13; ; chemical unit e; Sample 21-1, 5$8 \mathrm{~cm}$.

This sample contains abundant fractured olivine phenocrysts and microphenocrysts in a dark aphanitic matrix containing acicular "belt-buckle" plagioclase and quench olivine enveloped by intergrowths of plagioclase, pyroxene, and opaque oxides. The LIL elements are fairly low in concentration, but they are not as depleted as in Unit 1 of this site.

Lithologic Unit 5(14) and (15); chemical unit f; Samples $22-2$, 4-5 cm; 22-3, 47-53 cm; 23-3, 83-85 cm; 23-3, 106$108 \mathrm{~cm}$.

The glass from $22-2$ is variolitic, with olivine and plagioclase microphenocrysts. There are a few large plagioclase-olivine glomerocrysts in 22-3 with microphenocrysts of olivine and plagioclase, the latter is complexly zoned. Circular chondrule-like structures 2-4 $\mathrm{mm}$ in diameter are common, and they appear to be largely composed of radial aggregates of pyroxene and interstitial oxides. In the matrix, plagioclase-pyroxeneoxide intergrowths abound. The sample from 23-3 is similar, but olivine is less abundant. The plagioclase phenocrysts in 22-3 average about An77 and microphenocrysts range down to $\mathrm{An}_{70}$. Total $\mathrm{Fe}+\mathrm{Mg}$ increases with increasing albite content and perhaps also with increasing rate of quenching, but the $\mathrm{Fe} / \mathrm{Mg}$ ratio remains close to 1.0 in all samples. This is typical of plagioclase which does not coprecipitate with pyroxene. The olivines are somewhat variable in composition but more magnesian than those from Unit 3 of this hole.

Chemically this unit appears intermediate in character, plotting midway on the $\mathrm{TiO}_{2}-\mathrm{FeO}^{k} / \mathrm{MgO}$ and $\mathrm{V}-\mathrm{Zr}$ plots (Figures 1 and 2). REE are about $10 \times$ chondrite with a slight LREE depletion (Figure 3). Other LIL elements are intermediate in concentration compared to Units 1, 2, and 3 of this hole.

Lithologic Unit 6; chemical unit g.

This unit is extremely variable in petrography and composition. Although all samples are classified in 
TABLE 4

Leg 37 Site 335

Mineral Analyses

\begin{tabular}{|c|c|c|}
\hline & \multicolumn{2}{|c|}{ Olivine } \\
\hline & 1 & 2 \\
\hline $\mathrm{SiO}_{2}$ & 39.91 & 39.78 \\
\hline $\mathrm{TiO}_{2}^{2}$ & 0.03 & 0.02 \\
\hline $\mathrm{Al}_{2} \mathrm{O}_{2}$ & 0.05 & 0.06 \\
\hline $\mathrm{FeO}^{2}$ & 14.09 & 13.09 \\
\hline $\mathrm{MnO}$ & 0.20 & 0.22 \\
\hline $\mathrm{MgO}$ & 46.26 & 46.83 \\
\hline $\mathrm{CaO}$ & 0.32 & 0.33 \\
\hline $\mathrm{Na}_{2} \mathrm{O}$ & 0.05 & 0.08 \\
\hline $\mathrm{K}_{2} \mathrm{O}$ & 0.00 & 0.00 \\
\hline $\mathrm{Cr}_{2} \mathrm{O}_{3}$ & 0.03 & 0.03 \\
\hline \multirow[t]{3}{*}{ Total } & 100.95 & 100.45 \\
\hline & \multicolumn{2}{|l|}{ Cations } \\
\hline & \multicolumn{2}{|l|}{4 Oxygen } \\
\hline $\mathrm{Si}$ & 0.990 & 0.987 \\
\hline $\mathrm{Ti}$ & 0.000 & 0.000 \\
\hline $\mathrm{Al}$ & 0.001 & 0.001 \\
\hline $\mathrm{Fe}$ & 0.292 & 0.271 \\
\hline $\mathrm{Mn}$ & 0.003 & 0.004 \\
\hline $\mathrm{Mg}$ & 1.710 & 1.733 \\
\hline $\mathrm{Ca}$ & 0.008 & 0.008 \\
\hline $\mathrm{Na}$ & 0.002 & 0.003 \\
\hline $\mathrm{K}$ & 0.000 & 0.000 \\
\hline $\mathrm{Cr}$ & 0.000 & 0.000 \\
\hline Total & 3.006 & 3.008 \\
\hline \multicolumn{3}{|c|}{$\begin{array}{l}\text { Note: } 1=6-1,47-49 \mathrm{~cm} \\
\text { olivine microphenocryst in } \\
\text { glass; } 2=8-3,98-101 \mathrm{~cm} \\
\text { olivine microphenocryst in } \\
\text { glass. }\end{array}$} \\
\hline
\end{tabular}

chemical unit $\mathrm{g}$, we recognize three distinct subunits.

Lithologic Unit 6(16) and (17); Samples 25-3, 12-13 cm; $25-4,19-21 \mathrm{~cm}$.

These samples are microdolerites with plagioclaseolivine glomerocrysts and olivine phenocrysts. Rare spinel microphenocrysts are present as well as extremely rare pyroxene microphenocrysts. The pyroxene is the most iron rich of the pyroxenes analyzed from Hole 332B. Except for higher $\mathrm{Cr}$, Co, and $\mathrm{Ni}$ abundances, these samples are very similar to those of the overlying Unit 5.

Lithologic Unit 6(18; Sample 27-2, 76-78 cm.

This sample consists of glomerocrysts of plagioclase in a matrix of coarse and fine radial aggregates of plagioclase and pyroxene. Olivine and pyroxene phenocrysts are not present. Chemically this unit has a high $\mathrm{FeO} / \mathrm{MgO}(>1.3)$ and high concentrations of $\mathrm{TiO}_{2}$ $(>1.0), \mathrm{Ba}, \mathrm{V}$, and $\mathrm{Zr}$. The REE are about $15 \times$ chondrites with a slight but definite LREE enrichment (Figure 3). This sample appears to be a fractionated lava similar to Units 2 and 3 of this hole and Unit 3 from Hole 332A.

Lithologic Unit 6(19); Samples 29-1, 74-77 cm; 29-2, $57-60 \mathrm{~cm}$.

These samples have abundant olivine phenocrysts and large spinel microphenocrysts in an altered doleritic matrix. The high olivine and spinel accumula- tion is reflected in the high $\mathrm{Cr}(1000-1500 \mathrm{ppm})$ and $\mathrm{Ni}$ (340-460 ppm) contents. The LIL-elements such as $\mathrm{Zr}$, $\mathrm{Ba}$, and $\mathrm{V}$ are relatively low in concentration. This unit has trace element abundances very similar to Unit $4{ }_{113}$, of this hole.

Lithologic Unit 7,23; ; chemical unit h; Samples 35-2, $51-58 \mathrm{~cm} ; 35-2,62-65 \mathrm{~cm}$.

Petrographically these samples are very similar to Unit 6.191-large olivine phenocrysts and scattered spinel microphenocrysts are enclosed in a coarse subophitic doleritic matrix. Euhedral olivine phenocrysts and microphenocrysts as well as fractured and deformed crystal fragments have similar compositions near Fo(90). As with Unit 6(19, high $\mathrm{Mg}, \mathrm{Cr}$, and $\mathrm{Ni}$ abundances reflect the cumulate nature of the samples. The REE are similar in distribution and abundance to Unit 1 of this hole (Figure 3), but $\mathrm{Zr}$ and $\mathrm{Y}$ concentrations are slightly higher in Unit 7.

Lithologic Unit 8(25); chemical unit i; Samples 36-2, $81-83 \mathrm{~cm} ; 36-3,105-113 \mathrm{~cm} ; 36-5,5-7 \mathrm{~cm} ; 37-2,72-74$ $\mathrm{cm}$.

The glass at 36-3 has only plagioclase phenocrysts with varioles centered on tiny plagioclase microlites. Thin sections show plagioclase xenocrysts in an aphanitic plagioclase-pyroxene

Unit 1 of this hole, has plagioclase as the dominant liquidus phase. Chemically, it is somewhat similar to Unit 1 but the slightly higher concentrations of $\mathrm{Ti}, \mathrm{Zr}$, and $\mathrm{REE}$ and higher $\mathrm{FeO}^{*} / \mathrm{MgO}$ indicate a slightly more fractionated liquid (Figures 1, 2, and 3).

Lithologic Unit 9i26); chemical unit j; Samples 37-3, $11-13 \mathrm{~cm}$.

Olivine phenocrysts and spinel and plagioclase microphenocrysts are contained in a microdoleritic matrix with 20\%-30\% alteration. Except in the $\mathrm{Cr}$ and $\mathrm{Ni}$ concentrations, reflecting the olivine and spinel abundance, this unit is not greatly different from Unit 13. LIL elements are similar in abundance to Unit 13.

Lithologic Unit 10,411; chemical unit k; Samples 43-3, $109-110 \mathrm{~cm} ; 44-3,144-146 \mathrm{~cm}$.

The sample from $43-3$ is palagonite with preserved plagioclase microphenocrysts. There are no obvious olivine relicts. In 44-3, plagioclase xenocrysts and rare plagioclase-augite glomerocrysts are associated with chloritized phenocryst pseudomorphs which may have been augite. The groundmass contains abundant plagioclase-pyroxene "bow-tie" intergrowths. Plagioclase from this unit has a higher $\mathrm{Fe} / \mathrm{Mg}$ ratio than plagioclase from Unit 5 of this hole. This result is consistent with the relatively high $\mathrm{Zr}, \mathrm{Ba}$, and $\mathrm{REE}$ abundances (Figures 2 and 3 ) which indicate a fractionated lava similar to Units 2 and 3 of Hole 332B.

\section{Site 333A}

Lithologic Unit 2; Samples 3-1, 74-77 cm; 3-1, 75-76 $\mathrm{cm}$ (two splits from same core); Lithologic Unit 3; Sample 6-2, 26-33 cm; Lithologic Unit 7; Sample 10-2, 74-78 $\mathrm{cm}$.

Samples from 3-1 and 10-2 are microdolerites with subophitic textures. Complex plagioclase-pyroxene intergrowths are common. The plagioclase xenocrysts or phenocrysts are compositionally zoned from labra- 


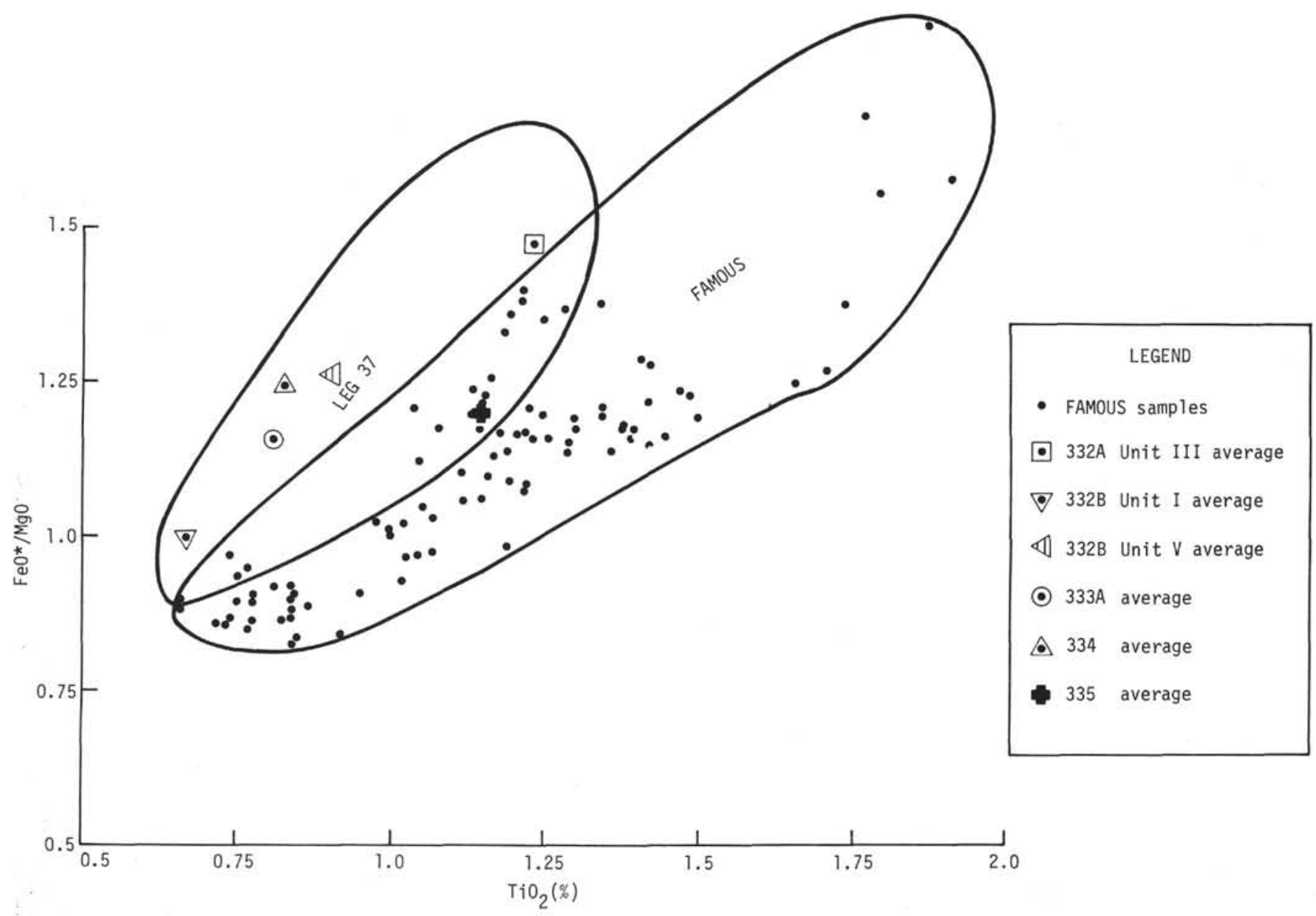

Figure 1. $\mathrm{FeO} * / \mathrm{MgO}$ versus $\mathrm{TiO}_{2}$ concentrations for basalts from Leg 37 sites and the Median Valley at about $37^{\circ} \mathrm{N}$ latitude (FAMOUS area).

dorite to oligoclase. Pyroxene is selectively altered to chlorite. Sample 10-2 contains a pyroxene phenocryst. The sample from 6-2 is aphanitic, but plagioclase microphenocrysts and quench pyroxenes are evident.

Chemically, Unit 2 is characterized by intermediate $\mathrm{FeO}^{*} / \mathrm{MgO}, \mathrm{Ba}, \mathrm{V}, \mathrm{Zr}, \mathrm{Cr}$, and $\mathrm{Ni}$ abundances. $\mathrm{REE}$ abundances are about $10 \times$ chondrite with a nearly chondritic distribution (Figure 4). Units 3 and 7 are somewhat more enriched in $\mathrm{Cr}, \mathrm{Ni}$, and LIL elements than Unit 2. The high LIL element abundances are consistent with a relatively fractionated liquid as implied by liquidus pyroxene.

\section{Site 334}

Lithologic Unit 1; Sample 16-3, 24-31 cm; Lithologic Unit 2; Sample 19-2, 17-19 cm.

The sample from $16-3$ is a microdolerite with plagioclase phenocrysts in a subophitic matrix with coarse magnetite octahedra. The texture resembles that found in the center of large lava pillows and suggests an extrusive origin. The pyroxene in this unit is an aluminous chrome diopside. Sample 19-2 is a glass with abundant olivine and plagioclase microphenocrysts. Both units are similar chemically with intermediate LIL-element abundances similar to Unit 10 of Hole
332B. However, Unit 10 of Hole 332B is slightly more evolved with higher $\mathrm{FeO}^{*} / \mathrm{MgO}$ and LIL-element abundances and lower $\mathrm{Ni}$ abundance.

Lithologic Unit 3; Samples 21-1, 36-47 cm; 22-2, 34$35 \mathrm{~cm} ; 27-1,32-50 \mathrm{~cm}$.

These are coarsely crystalline plutonic rocks containing olivine, clinopyroxene, orthopyroxene, and plagioclase in varying proportions. The sample from 22-2 is largely serpentinized with remnants of olivine and pyroxene; no relict plagioclase was observed. The sample from 27-1 appears to be a serpentinized olivine gabbro. Grain sizes are typically $4-5 \mathrm{~mm}$ and mineral distribution is random; no evidence of sorting or layering was observed.

Pyroxene analyses from 21-1 indicate the hypersthene to be distinctly lower in $\mathrm{TiO}_{2}$ and $\mathrm{Al}_{2} \mathrm{O}_{3}$ than the augite, a typical relation when these minerals coexist. Lamellae in exsolved augites differ mainly in $\mathrm{CaO}$ content, with the pigeonite bands being slightly more Fe-enriched. Plagioclase varies little in composition; it is an intermediate bytownite with very high $\mathrm{FeO} / \mathrm{MgO}$ ratio. Compared to mineral phases in the lavas, the augite is similar to the basalt augites, however, hypersthene was not observed in the basalts. The plagioclase is similar to the bytownite that 


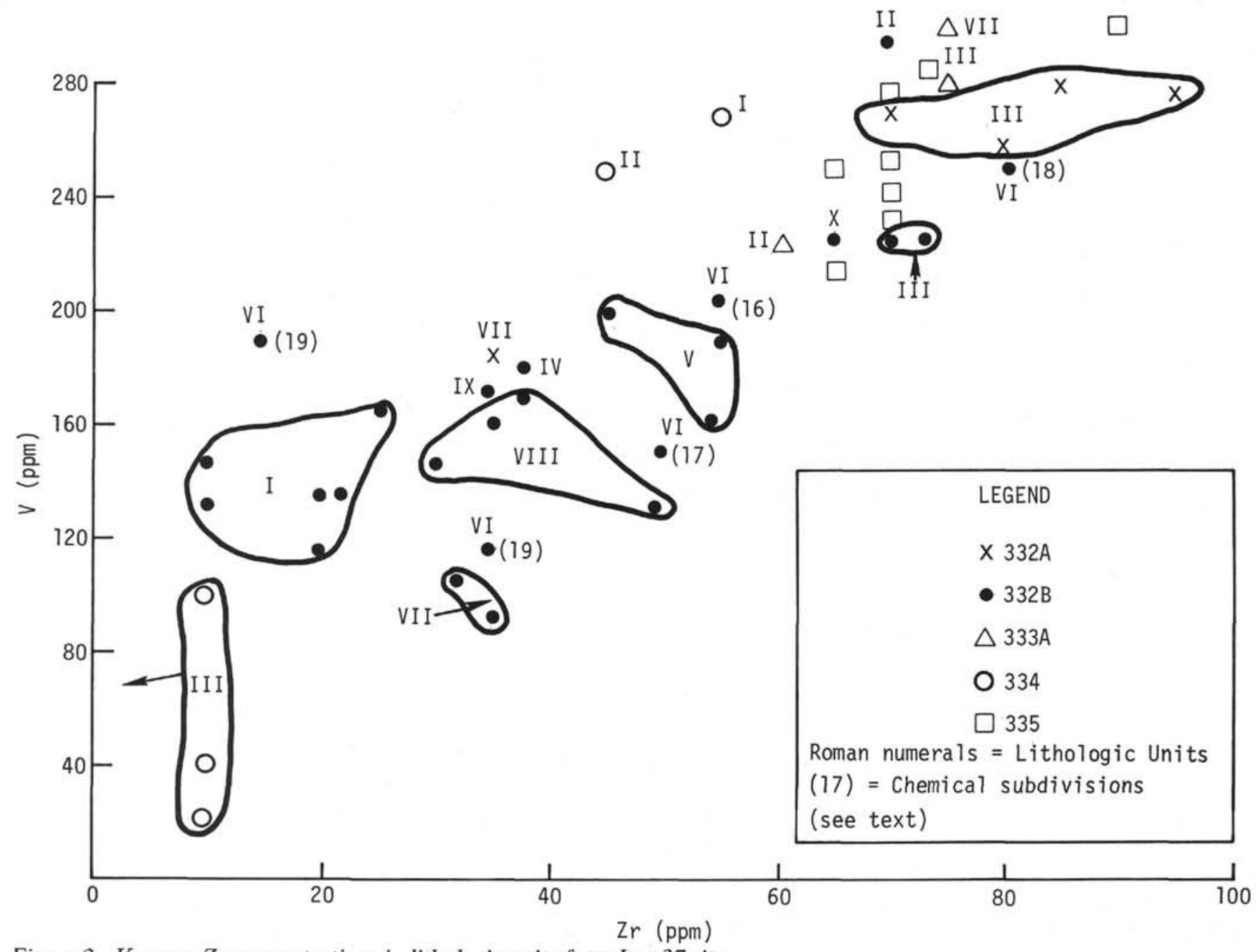

Figure 2. V versus $\mathrm{Zr}$ concentrations in lithologic units from Leg 37 sites.

coprecipitates with pyroxene in the lavas, but the basaltic plagioclase typically contains more $\mathrm{MgO}$ relative to $\mathrm{FeO}$.

Chemically these plutonic rocks are all characterized by very low REE abundances and positive Eu anomalies (Figure 4), and very low concentrations of LIL-elements such as $\mathrm{Ba}, \mathrm{Zr}$, and $\mathrm{V}$ (Figure 2). The major element composition of 21-1 gabbro is not greatly different from some of the aphyric basalts, thus the low LIL-element concentrations seem anomalous, particularly relative to the high $\mathrm{FeO}^{*} / \mathrm{MgO}$ (1.33). Apparently this gabbro is a cumulate with little trapped liquid; the relatively high alkalies being due to seawater alteration. Note, for example, the high $\mathrm{B}$ and $\mathrm{Li}$ contents. Samples from 22-2 and 27-1 are serpentinized peridotite and gabbro, respectively; thus, the high $\mathrm{Cr}$ and $\mathrm{Ni}$ and low LIL abundances are consistent with the petrography.

Site 335

Samples 6-1, 47-49 cm; 6-5, 110-112 cm; 8-2, 94-96 cm; 8-3, 98-101 cm; 8-4, 20-21 cm; 10-3, 100-102 cm; 10 $6,4-6 \mathrm{~cm} ; 11-1,62-64 \mathrm{~cm} ; 12-2,139-141 \mathrm{~cm}$.
Texturally these samples range from glass to microdolerite; probably representing different portions of lava pillows in an extrusive sequence. Mineralogically, all are characterized by olivine and plagioclase as liquidus phases. Rounded plagioclase xenocrysts, probably cognate, are common throughout the samples. At 12-2, a holocrystalline sample shows numerous chondrule-like patches formed of radial clusters of pyroxene and plagioclase. Some of these are partly hollow spheres as though they were gas bubbles only partly filled with silicate liquids; the remaining space is generally filled with chloritic material. Olivines from this site are intermediate in iron enrichment (Fo85${ }_{87)}$ and occur as phenocrysts, microphenocrysts, and skeletal "spinifex" growths in quenched glass. Sector zoning in the plagioclase is very common, more so than at other Leg 37 sites. Incipient plagioclase-pyroxene radial "sunbursts" or "rose-window" textures are common in the groundmass.

Chemically, these samples are remarkably uniform throughout the eruptive sequence. They are somewhat fractionated liquids with moderate $\mathrm{FeO}^{*} / \mathrm{MgO}(>1.0)$, $\mathrm{TiO}_{2}(>1.1 \%), \mathrm{Ba}, \mathrm{Zr}, \mathrm{V}$, and $\mathrm{Y}$ concentrations. $\mathrm{Cr}$ and 

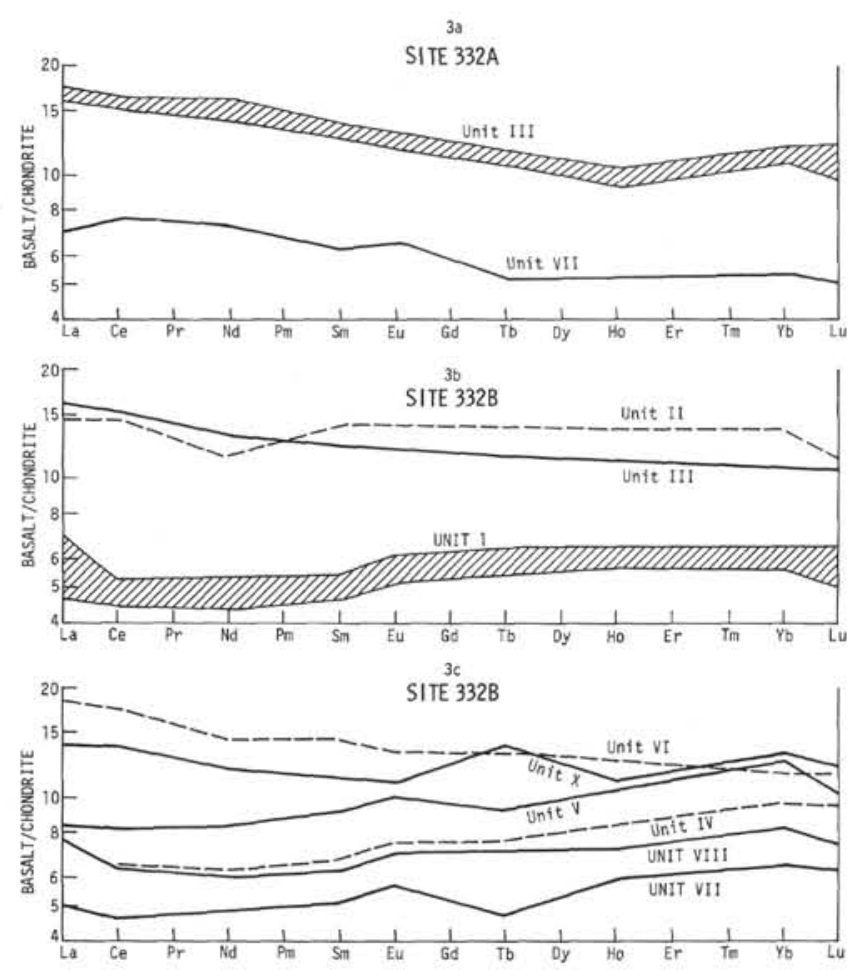

Figure 3. Rare-earth-element distributions in Leg 37 basalts relative to chondrites. (a) Hole $332 \mathrm{~A}$. Unit 3 , range for Samples 40-2, $133 \mathrm{~cm} ; 8-1,56-64 \mathrm{~cm} ; 8-2,2-15 \mathrm{~cm}$. Unit 7, Sample 40-2, 26-33 cm. (b) Hole 332B. Unit 1, range for Samples 3-4, 26-36 cm; 3-4, 40-43 cm; 3-4, 98-101 $\mathrm{cm}$. Unit 2, Sample 6-2, 122-125 cm. Unit 3, Sample 11-3, 75-78 cm. (c) Hole 332B. Unit 7, Sample 35-2, $62-65 \mathrm{~cm}$. Unit 8 Sample $36-3,105-113 \mathrm{~cm}$. Unit 4, Sample 21-1, 5-8 cm. Unit 5, Sample 22-3, $47-53 \mathrm{~cm}$. Unit 6, Sample 27-2, 76-78 cm. Unit 10, Sample 44-3, $144-146 \mathrm{~cm}$.

Ni concentrations are fairly high $(350-500 \mathrm{ppm} \mathrm{Cr}, 80-$ $150 \mathrm{ppm} \mathrm{Ni}$. The REE distributions are 10-15× chondrites but with slight LREE depletion. These lavas are intermediate in composition between the slightly fractionated basalts of Unit 5, Hole 332B, and the fractionated lavas of Unit 3, Hole 332A.

\section{DISCUSSION}

\section{Mineralogical and Geochemical Relationships}

Our data indicate consistencies between the nature and composition of liquidus mineral phases and geochemical variations. In general, olivine-spinel phenocryst assemblages are associated with low $\mathrm{FeO}^{*} / \mathrm{MgO}$, high $\mathrm{MgO}, \mathrm{Cr}$, and $\mathrm{Ni}$, and low $\mathrm{TiO}_{2}, \mathrm{Zr}, \mathrm{V}$, and $\mathrm{Ba}$ abundances. Olivine-plagioclase phenocryst assemblages are associated with lavas of intermediate geochemical character. Samples in which plagioclase and/or pyroxene are prominent liquidus phases show relatively high $\mathrm{FeO}^{*} / \mathrm{MgO}, \mathrm{TiO}_{2}, \mathrm{Zr}, \mathrm{V}, \mathrm{Ba}$, and $\mathrm{Y}$, and low $\mathrm{Cr}$ and $\mathrm{Ni}$ abundances. Further, within specific mineralogical groups, relatively high LIL-element concentrations tend to be associated with minerals having
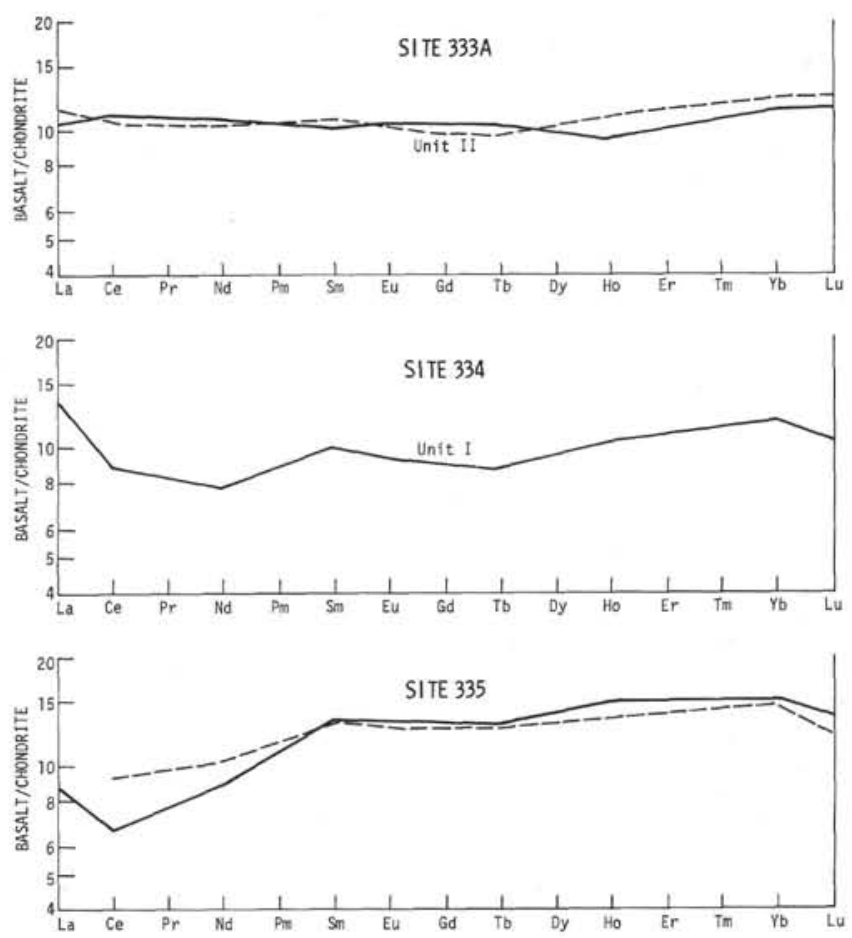

Figure 4. Rare-earth-element distributions in Leg 37 basalts relative to chondrites. (a) Hole 333A. Unit 2, Sample 3-1, 47-77 cm; fresh (-) and weathered (--) portions. (b) Site 334. Unit 1, Sample 16-3, 24-31 cm. The plutonic rocks from this site have REE distributions that range from 1.4-3.5 $x$ chondrites for $L u$ to $0.5 x$ chondrites for $L a$. (c) Site 335. Samples 8-2, 94-96 cm (-) and 8-3, 98-101 $\mathrm{cm}(-)$.

higher $\mathrm{FeO}^{*} / \mathrm{MgO}$ ratios. Anomalous geochemical features, such as positive europium anomalies or unusually high $\mathrm{Cr}$ and $\mathrm{Ni}$ abundances are associated with crystal cumulates of plagioclase and olivine, respectively.

Coexisting olivine, pyroxene, and plagioclase microphenocrysts and microlites in two glass samples from Hole $332 \mathrm{~A}$ suggest a three-phase cotectic. Less geochemically evolved samples typically have coprecipitated olivine and plagioclase, suggesting that they lie on a two-phase cotectic. The least evolved liquids also have spinel as a microphenocryst. These phase relations suggest that compositional variations can be approximated by cotectic crystallization, or minimummelting liquids, from a bulk parent composition lying within the natural equivalent to the end-member diopside-forsterite-anorthite system.

\section{Comparison with Rocks from the FAMOUS Area}

Major element and petrographic data are available for some 100 basalt glasses collected by dredging and submersibles in and near the Median Valley about 33 $\mathrm{km}$ east of Hole 332B (FAMOUS area). These samples and Leg 37 rocks presumably originated at the same spreading center. Our Leg 37 glass and bulk rock analyses, and a set of $61 \mathrm{Leg} 37$ glass analyses provided by W.G. Melson, allow comparisons between Leg 37 and FAMOUS area rocks. 
Significant major element parameters are $\mathrm{FeO}^{*} / \mathrm{MgO}$ ratio and $\mathrm{TiO}_{2}$ abundance. For the FAMOUS rock glasses, the ranges are: $\mathrm{FeO}^{*} / \mathrm{MgO}$ $0.75-1.83 ; \mathrm{TiO}_{2} 0.50-1.91$. For the Leg 37 glasses, the ranges are: $\mathrm{FeO} * / \mathrm{MgO} 0.90-1.55 ; \mathrm{TiO}_{2}$ 0.64-1.28. In general, both data sets show a positive correlation between $\mathrm{FeO}^{*} / \mathrm{MgO}$ and $\mathrm{TiO}_{2}$. However, there is considerable scatter in the data, and the Leg 37 glasses tend to have higher $\mathrm{FeO}^{*} / \mathrm{MgO}$ ratios at a given $\mathrm{TiO}_{2}$ content (Figure 1).

In the Median Valley, low $\mathrm{TiO}_{2}$, low $\mathrm{FeO}^{*}$ basalts with liquidus olivine and spinel are typical of the young central volcanic highs on the valley floor. These partly cover older lavas which are more fractionated chemically and mineralogically. These more fractionated lithologies are also typical of the eastern and western walls and rift mountains. Many of the flank lavas are characterized by an abundance of plagioclase phenocrysts, while olivine cumulates are typical of some flows in the central valley. A reasonable interpretation of these relations suggests that, as the central lavas are carried past the margins of the valley they tend to be covered by more fractionated younger flank eruptions. Some fractionation must also be postulated within the central valley to account for the older fractionated lavas observed there. This should produce a relatively complex lava stratigraphy, with possible interlayering of several batches of fractionated and less fractionated lavas, the older (lower) units tending to have been erupted in or near the central valley, and the younger lavas tending to have been erupted on the flanks. Qualitatively, this may account for the alternate interlayered plagioclase- and olivine-rich basalts in Hole 332B.

Samples collected by the submersible Alvin from the west and east walls of the Median Valley have higher
$\mathrm{TiO}_{2}$ (up to 1.50 wt \%), and generally lower $\mathrm{FeO} * / \mathrm{MgO}$ $(<1.30)$ which places them outside the Leg 37 range (Figure 1). The high $\mathrm{TiO}_{2}(>1.50 \mathrm{wt} \%)$, high $\mathrm{FeO}^{*} / \mathrm{MgO}(>1.30)$ lavas of the FAMOUS area are from fracture zone B and the central rift valley south of that fracture; these are the lavas which include olivinepyroxene-plagioclase liquidus assemblages.

These observations suggest that a rather complex lava stratigraphy is to be expected and that there may have been subtle changes in magma chemistry with time. Although petrographic variations are similar in the FAMOUS and Leg 37 areas, the rather simple fractionation scheme that they suggest may be imposed on starting materials which differ fundamentally in their $\mathrm{FeO}^{*} / \mathrm{MgO}$ ratios and $\mathrm{TiO}_{2}$ content and which may prove to differ in other important geochemical parameters as well.

\section{ACKNOWLEDGMENTS}

This research was supported by National Science Foundation Grants GA-41393 with the Woods Hole Oceanographic Institution, and GA-41403 with Massachusetts Institute of Technology. We thank J. Guertler, D.C. Bankston, M. Sulanowsky, and R. Houghton for their assistance in obtaining experimental data. This is Woods Hole Oceanographic Institution Contribution No. 3833.

\section{REFERENCES}

Bryan, W.B., 1974. Sector-zoning and Fe-Mg relationships in submarine basalt plagioclase: Earth Planet. Sci. Lett., v. 24, p. $157-165$.

Frey, F.A., Bryan, W.B., and Thompson, G., 1974. Atlantic ocean floor: geochemistry and petrology of basalts from Legs 2 and 3 of the Deep-Sea Drilling Program: J. Geophys. Res., v. 79, p. 5507-5527. 